Syntax Fusion : Jurnal Nasional Indonesia

e-ISSN : 2775-4440

Vol. 1, No. 9, September 2021

\title{
IMPLEMENTASI SUPERVISI KEPALA SEKOLAH DALAM PENINGKATAN STRATEGI PEMBELAJARAN DI SD NEGERI 1 TELUK BETUNG KECAMATAN KARAU KUALA
}

\section{Retiana}

SD Negeri 1 Teluk Betung

Email: retiana.s.pd.sd@gmail.com

\begin{abstract}
Abstrak
Tujuan penelitian ini adalah untuk mengetahui pelaksanaan supervisi dan supervisi, mendeskripsikan strategi peningkatan pembelajaran, dan mengidentifikasi faktorfaktor yang mendukung dan menghambat pelaksanaan supervisi dan supervisi di SD Negeri 1 Teluk Betung untuk meningkatkan pembelajaran yang berlokasi di Kecamatan Kalauguara, Kabupaten Barito Selatan. Penelitian ini dilaksanakan di SD Negeri 1 Teluk Betung Kecamatan Kalauguara. Melaksanakan pembelajaran di bawah bimbingan rencana yang direncanakan. Kemudian evaluasi akan dilakukan setelah siswa menyelesaikan studi dalam jangka waktu sesuai dengan rencana kegiatan. Siswa dengan nilai lebih tinggi dari KKM akan diperkaya, sedangkan siswa dengan nilai lebih rendah dari KKM akan mendapatkan bimbingan belajar. Melaksanakan supervisi dan supervisi di SD Negeri 1 Teluk Betung Kecamatan Karau Kuala Kabupaten Barito Selatan untuk meningkatkan faktor penghambat dan pendukung pembelajaran Faktor penghambat tersebut antara lain: a) Pengadaan tenaga, sarana dan dana yang diperlukan untuk melaksanakan rencana supervisi yang baik; b) Kegiatan Supervisi Kepala Sekolah hanya akan dilakukan apabila dinas setempat telah mengeluarkan dana kegiatan supervisi; c) Kurangnya pelatihan bagi pengawas, dan guru belum mendapatkan pelatihan pelaksanaan K13; d) Masih ada guru yang tidak membayar memperhatikan RPP, e) Guru masih belum memahami K13. Faktor pendukungnya antara lain: supervisi kunjungan kelas secara terus menerus, supervisi dan dorongan guru untuk mengoptimalkan pekerjaannya.
\end{abstract}

Kata Kunci: Strategi Pembelajaran, Supervisi, Kepala Sekolah

\section{Pendahuluan}

Pendidikan pada dasarnya adalah proses belajar mengajar untuk mencapai tujuan pendidikan. Untuk mencapai tujuan pendidikan yang baik dan bermutu serta berhasil maka 
diperlukan fungsi kontrol yang cukup dan mencakup perhatian (monitoring), pengawasan dengan komponen-komponen pendidikan yang berupa supervisi pendidikan. P. Adam Smith dan Frank, G. Dicky dalam Daryanto berpendapat supervisi pendidikan merupakan suatu program yang terencana untuk memperbaiki pengajaran.

Dari kondisi internal sekolah negeri dan swasta, kualitas dan kuantitas guru masih menjadi kendala utama. Namun, yang sangat mendesak untuk diselesaikan adalah kualitas guru, karena kebijakan pemerintah di bidang pendidikan seringkali berubah, terutama kurikulum.

Dalam proses menjalankan tugasnya, guru tidak terlepas dari sulitnya mencapai tujuan yang telah ditetapkan oleh sekolah dan lembaga yang lebih tinggi. Oleh karena itu, peran pengajar adalah membantu menjelaskan dan mengoreksi kesalahan yang dilakukan oleh guru sekolah, terutama dalam merumuskan RPP, dan bagaimana menggerakkan semangat siswa di setiap kelas.

Kepala sekolah adalah orang utama selain guru, yang diberi tanggung jawab dan kekuasaan penuh untuk mengevaluasi dan membimbing teknologi pendidikan dan administrasi. Tugas kepala sekolah adalah mengembangkan proses pembelajaran di sekolah dalam bentuk kegiatan intra dan ekstra kurikuler.

Kepala sekolah merupakan salah satu pendidik yang memiliki harapan tinggi kepada guru untuk membantu dan membimbing guru dalam meningkatkan kualitas pembelajaran, sehingga tujuan pendidikan sekolah dapat tercapai dengan baik. Demikian pula diperlukan hubungan yang terkoordinasi dan berkesinambungan antara kepala sekolah dan guru dalam rangka melaksanakan berbagai kegiatan untuk meningkatkan prestasi siswa.

Kegiatan supervisi menitikberatkan pada pendampingan yang dapat meningkatkan kemampuan profesional, yang tercermin dari kemampuan guru dalam memberikan bantuan belajar kepada siswa, yang berujung pada perubahan perilaku akademik siswa.

Supervisi dilakukan secara konstruktif dan kreatif oleh kepala sekolah sebagai supervisor, mendorong guru untuk berinisiatif berpartisipasi, menciptakan suasana yang kondusif, dan membangkitkan suasana kreatif siswa dalam belajar. Pengawas melakukan tugas profesional yang dilakukan oleh klien, atau dewan pengawas dilakukan sesuai dengan prinsip pengawasan yang lebih berkualitas.

Keberadaan kepala sekolah lembaga pendidikan sekolah adalah untuk mendorong dan membantu guru memecahkan berbagai jenis dan bentuk permasalahan dalam pelaksanaan pembelajaran, dan menjadi mitra dalam pelaksanaan pembelajaran, namun kenyataannya berbeda dengan yang diinginkan. Di bidang pendidikan dan pengajaran, kita membutuhkan seorang supervisor yang dapat berbicara dan membantu pertumbuhan pribadi dan profesional, sehingga setiap orang dapat mengalami peningkatan pribadi dan profesional.

Keberhasilan penyelenggaraan pendidikan yang berkualitas erat kaitannya dengan keberhasilan peningkatan kemampuan dan profesionalisme pendidik dan tenaga kependidikan. Kepala sekolah merupakan salah satu pendidik dan tenaga kependidikan, dan 
Retiana

posisinya memegang peranan strategis yang penting dalam meningkatkan profesionalisme guru dan mutu pendidikan sekolah. Dengan kondisi saat ini di bidang ini, tentunya masih banyak kepala sekolah yang belum memahami enam dimensi kemampuan dengan baik. Kepala sekolah harus memiliki kualifikasi dan kemampuan yang memadai untuk melaksanakan tugas pengawasannya. Salah satu tugas kepala sekolah yang profesional adalah melaksanakan kegiatan supervisi akademik, serta memberikan bimbingan dan pelatihan profesional yang optimal kepada guru.

Setelah peran kepala sekolah dalam menentukan mutu pendidikan menjadi penting, maka pengawas sekolah akan berperan aktif dalam meningkatkan materi yang diberikan oleh pendidik kepada siswa.

Kepala sekolah merupakan bagian penting dalam peningkatan mutu pendidikan sekolah. Di bawah pengawasan kepala sekolah, semangat dan optimalisasi kerja akan ditumbuhkan untuk mencapai tujuan pendidikan. Salah satu kinerja kepala sekolah harus dilihat dari kemajuan yang dicapai sekolah binaan. Dalam keadaan ini, mutu pendidikan sekolah yang dibinanya akan sangat bergantung pada kemampuan profesional kepala sekolah.

Tugas kepala sekolah merupakan tugas penting untuk meningkatkan mutu pendidikan, pada saat yang sama kepala sekolah harus memiliki kemampuan untuk memenuhi kebutuhan pendidikan, oleh karena itu kualitas kepala sekolah harus dijaga dengan baik untuk memenuhi persyaratan tersebut. Melalui pendidikan. Sesuai dengan tanggung jawab kepala sekolah dalam bidang manajemen dan akademik untuk mengarahkan sekolah, kualitas kinerja kepala sekolah perlu diperhatikan lebih lanjut, karena kondisi kepala sekolah masih belum memenuhi standar yang ditetapkan pemerintah. Tugas kepala sekolah adalah melindungi segala sesuatu yang ada di sekolah, mulai dari guru, tenaga kependidikan, dan asisten laboratorium, ketika kepala sekolah belum memiliki kemampuan yang matang dan pengetahuan yang lebih dari pendidik sekolah, maka manajemen bukanlah tugas yang mudah.

Tugas evaluasi dan konseling oleh kepala sekolah bukanlah tugas yang mudah, karena bukan sekedar kunjungan ke sekolah tanpa ada tindak lanjut. Tugas penilaian dan pelatihan menuntut siswa untuk memiliki kemampuan mengamati situasi sekolah dengan cermat, ketajaman analisis dan sintesis, ketepatan memberikan perlakuan yang diperlukan, dan komunikasi yang baik antara pengawas sekolah dan semua orang di sekolah. Yang dimaksud dengan bimbingan belajar itu sendiri adalah memberikan arahan, bimbingan, contoh dan saran bagi terselenggaranya pendidikan sekolah. Dengan kemampuan tersebut, saya berharap kepala sekolah dapat menjadi mitra kerja yang harmonis dengan guru.

Pengawasan terbaik terhadap pelaksanaan tugas dan tanggung jawab kepala sekolah tidak hanya didasarkan pada kepemimpinan dan keterampilan, tetapi juga didukung oleh sikap positif dan konstruktif, seperti dedikasi, ketekunan, disiplin, inisiatif, tanggung jawab, komunikasi, persuasi, kritik, dan keterbukaan. Hubungan antara supervisor/supervisor 
dengan orang yang disupervisi lebih bersifat kemitraan, dan hubungan komunikasi tidak lagi merupakan operasi tersendiri tetapi merupakan kerjasama operasi atau kerja sama..

\section{Metode Penelitian}

Penelitian ini adalah penelitian langsung yang bersifat deskriptif kualitatif yang merupakan suatu bentuk penelitian ditujukan untuk mendeskripsikan fenomena- fenomena yang ada, baik fenomena alamiah maupun fenomena buatan manusia. Fenomena itu bisa berupa bentuk, aktivitas, karakteristik, perubahan, hubungan, kesamaan, dan perbedaan antara fenomena yang satu dengan fenomena lainnya.

Jenis penelitian ini bersifat kualitatif yaitu penelitian yang berusaha menangkap gejala secara holistik kontekstual melalui pengumpulan data dari subyek yang diteliti sebagai sumber langsung dengan instrumen kunci peneliti sendiri, yaitu peneliti merupakan perencana, pelaksana pengumpulan data, analisis, penafsir data, dan pada akhirnya ia menjadi pelapor hasil penelitiannya.

Dalam penelitian kualitatif misalnya, teknik pengumpulan data yang utama yaitu menggunakan daftar wawancara tertulis kepada informan, data yang diperoleh adalah data kualitatif. Selanjutnya untuk memperkuat dan mengecek validitas data hasil wawancara tersebut, maka dapat dilengkapi dengan observasi atau wawancara kepada informan yang telah memberikan jawaban pertanyaan yang diajukan penulis, atau orang lain yang memahami terhadap masalah yang diteliti. Sehingga dengan

adanya data kualitatif melalui wawancara mendalam kepada pihak pengelola yang berwenang memberikan informasi sehingga penulis dapat menyusun suatu proporsi.

Dapat dikatakan bahwa penelitian kualitatif yang dimaksudkan ini adalah suatu upaya untuk mengungkapkan secara mendalam mengenai beberapa hal yang berkaitan dengan implementasi supervisi kepala sekolah dalam peningkatan pembelajaran di SD Negeri 1 Teluk Betung Kecamatan Karau Kuala Kabupaten Barito Selatan.

\section{Hasil Dan Pembahasan}

Tugas dan tanggungjawab kepala sekolah diarahkan untuk tercapainya tenaga pendidikan yang profesional. Profesionalisasi tenaga kependidikan dalam lingkup SD Negeri 1 Teluk Betung Kecamatan Karau Kuala Kabupaten Barito Selatan dengan semua kemampuan baik yang bersifat fisik maupun non fisik untuk membentuk, mengubah dan mengembangkan sesuatu yang ada di lingkungan SD Negeri 1 Teluk Betng Kecamatan Karau Kuala Kabupaten Barito Selatan untuk kepentingan pendidikan. tugas pokok pengawas sebagai berikut:

\section{Penyusunan Perencanaan pada satuan pendidikan}

Perencanaan adalah proses pemikiran secara matang dan sistematis untuk mengambil suatu keputusan mengenai aktivitas yang akan dilaksanakan di masa yang akan 
Retiana

datang menuju tujuan yang dikehendaki.

\section{Melaksanakan Pembinaan, Pemantauan dan Penilaian Penyelenggaraan Pendidikan.}

Kegiatan supervisi akademik meliputi pembinaan, pemantauan pelaksanaan delapan standar Nasional pendidikan yang terkait yang merupakan kegiatan yang bersifat interaksi langsung antara kepala sekolah, para guru dan tenaga kependidikan lainnya kegiatan ini adalah kegiatan tatap muka pengawas di satuan pendidikan binaannya. Adapun kegiatan yang terkait dengan mengolah hasil pemantauan setiap standar dari delapan standar Nasional pendidikan.

Menurut Muhtar, kepala sekolah mempunyai peran ganda sebagai kepala sekolah, yaitu berperan sebagai pemberi bantuan dan pembinaan profesi guru di satu sisi, dan sebagai penilai peformans mengajar guru untuk kepentingan upaya SD Negeri 1 Teluk Betng Kecamatan Karau Kuala Kabupaten Barito Selatan dalam mengimplementasikan supervisi tidak terlepas dari tugas pokok. Karena itu, kepala sekolah dalam lingkup SD Negeri 1 Teluk Betng Kecamatan Karau Kuala Kabupaten Barito Selatan dalam melaksanakan tugas harus mempunyai kecakapan dalam memupuk suasana hubungan antar pribadi yang sehat, yang melahirkan saling kepercayaan.

Kepala sekolah di SD Negeri 1 Teluk Betung Kecamatan Karau Kuala Kabupaten Barito Selatan mempunyai tugas dan tanggungjawab dalam administrasi operasional sekolah yaitu penciptaan lingkungan dan budaya sekolah juga peran serta masyarakat yang mencakup aspek keamanan dan ketertiban, kebersihan, dan kesehatan, keindahan dan kerindangan/penghijauan, kekeluargaan warga sekolah, budaya sekolah, dan peran serta masyarakat beserta uraian kegiatannya masing- masing, dari komite, kepala sekolah, pendidik, maupun tenaga kependidikan. Kepala Sekolah supervisinya juga membawa instrumen yang diberikan kepada guru jauh hari sebelum diadakan supervisi, dengan harapan warga sekolah juga mengerti hal-hal yang berkaitan dengan supervisi administrasi operasional.

Berdasar pada pandangan tersebut, memberikan gambaran bahwa kepala sekolah di SD Negeri 1 Teluk Betung Kecamatan Karau Kuala Kabupaten Barito Selatan secara administrasi melaksanakan pengawasan administratif, meliputi; administrasi sekolah secara umum, kesiswaan, ketenagaan, perlengkapan pendidikan, keuangan, dan hubungan sekolah dengan masyarakat. Tugas kepala sekolah membimbing guru dalam menyusun silabus tiap mata pelajaran, Kompetensi Inti (KI) dan kompetensi dasar (KD) serta prinsip- prinsip pengembangan kurikulum. Pengawas juga membimbing guru dalam memilih dan menggunakan strategi/metode maupun teknik pembelajaran, membimbing guru dalam menyusun Rencana Pelaksanaan Pembelajaran (RPP), membimbing guru dalam mengelola, merawat, mengembangkan dan menggunakan media pembelajaran serta memotivasi guru memanfaatkan teknologi informasi untuk pembelajaran.5

Keterangan di atas, kepala sekolah di SD Negeri 1 Teluk Betung Kecamatan Karau 
Kuala Kabupaten Barito Selatan memahami konsep, prinsip, teori dasar/teknologi, karakteristik dan kecenderungan tiap bidang pengembangan mata pelajaran Sekolah. Kepala sekolah membimbing guru dalam menyusun silabus tiap mata pelajaran, Kompetensi Inti (KI) dan kompetensi dasar (KD) serta prinsip- prinsip pengembangan kurikulum. Kepala sekolah juga membimbing guru dalam memilih dan menggunakan strategi/metode maupun teknik pembelajaran, membimbing guru dalam menyusun Rencana Pelaksanaan Pembelajaran (RPP), kepala sekolah membimbing guru dalam mengelola, merawat, mengembangkan dan menggunakan media pembelajaran serta memotivasi guru untuk memanfaatkan teknologi informasi untuk pembelajaran. Kepala sekolah pada SD Negeri 1 Teluk Betung Kecamatan Karau Kuala Kabupaten Barito Selatan , menerapkan supervisi maupun pembinaan secara intensif, sudah memberikan kontribusi dalam pengawasan akademik.

Artinya dari hasil wawancara dengan guru, guru SD Negeri 1 Teluk Betung Kecamatan Karau Kuala Kabupaten Barito Selatan telah memberikan kontribusi dalam pengawasan akademik. Hal ini terbukti bahwa SD Negeri 1 Teluk Betung Kecamatan Karau Kuala Kabupaten Barito Selatan menunjukkan kinerja yang optimal, proses pembelajaran (akademik) berjalan baik sesuai dengan kurikulum yang telah di buat oleh sekolah.

\section{Melaksanakan supervisi}

Tujuan utama supervisi pada SD Negeri 1 Teluk Betung Kecamatan Karau Kuala Kabupaten Barito Selatan dan memberikan bantuan teknis dan bimbingan kepada guru dan staf dan personil tesebut mampu meningkatkan kwalitas kinerjanya dalam melaksanakan tugas dan melaksanakan proses pembelajaran. Secara operasional dapat dikemukakan beberapa tujuan kongkrit supervisi pendidikan pada SD Negeri 1 Teluk Betung Kecamatan

Sedangkan menurut salah satu guru SD Negeri 1 Teluk Betung Kecamatan Karau Kuala Kabupaten Barito Selatan bahwa prinsip-prinsip supervisi yaitu Supervisi harus dilaksanakan secara demokratis dan kooperatif, kreatif dan konstruktif, scientific dan efektif, dan dapat memberi perasaan aman pada guru-guru, berdasarkan kenyataan.

Prinsip-prinsip supervisi di atas merupakan kaidah-kaidah yang harus dipedomani atau dijadikan landasan didalam melakukan supervisi, maka hal itu mendapat perhatian yang sungguh-sungguh dari supervisor, baik dalam konteks hubungan supervisor-guru, maupun didalam proses pelaksanaan supervisi.

Jadi fungsi utama supervisi pendidikan SD Negeri 1 Teluk Betung Kecamatan Karau Kuala Kabupaten Barito Selatan pada perbaikan dan peningkatan kualitas pengajaran. Sehingga dapat membina program pengajaran yang ada sebaik-baiknya sehingga selalu ada usaha perbaikan. Fungsi utama supervisi SD Negeri 1 Teluk Betung Kecamatan Karau Kuala Kabupaten Barito Selatan ialah menilai dan mempernbaiki faktor-faktor yang mempengaruhi proses pembelajaran peserta didik, dan fungsi utama supervisi bukan hanya perbaikan pembelajaran saja akan tetapi untuk mengkoordinasi, menstimulasi, dan mendorong kearah pertumbuhan profesi guru. 
Retiana

Implementasi manajemen dan supervisi di SD Negeri 1 Teluk Betung Kecamatan Karau Kuala Kabupaten Barito Selatan ditinjau dari segi perencanaanya dalam berbagai segi, dan hal itu ditemukan jika dilakukan pembandingan secara mendalam. Adapun bentuk dan implementasi perencanaan program pengajaran adalah berbentuk program tahunan, program semester, RPP, dan silabus. Dari perencanaan yang telah disusun tersebut diwajibkan kepada semua guru pada setiap jenjang dan unit kerja sebelum melaksanakan PBM di kelas, dengan bimbingan dan pengawasan langsung oleh Kepala sekolah. Implementasi perencanaan ini tetap mempertimbangkan baik ketegasan pemerintah sebagaimana tertuang dalam UndangUndang RI Nomor 20 tahun 2003, tentang Sistem Pendidikan Nasional bahwa kurikulum pada pola nasional berpedoman pada penyelenggaraan program kebijaksaan penerapan manajemen berbasis Sekolah.

Selain perencanaan dan supervisi secara terpadu, diterapkan pula manajemen metodologi pengajaran di SD Negeri 1 Teluk Betung Kecamatan Karau Kuala Kabupaten Barito Selatan, dan ini dapat dilihat saat terjadinya proses pembelajaran di kelas secara baik, aman dan terkendali karena telah direncanakan secara matang. Hasil observasi penulis secara langsung di lapangan, ditemukan kondisi saat guru mengajar, keadaan kelas dalam keadaan tenang, situasi seperti ini sering ditemukan bilamana ada tugas yang sedang diselesaikan oleh peserta didik. Setelah peserta didik selesai mengerjakan tugasnya keadaan kelas walaupun dalam keadaan normal tetapi terkadang pula ribut, sebagian peserta didik keluar dari kelas untuk keperluan mendesak yang sebelumnya meminta izin kepada guru yang bersangkutan. Situasi seperti yang disebutkan ini, menjadikan guru untuk menerapkan perencaaan tindakan kelas yang sesuai, sehingga terwujud proses pembelajaran yang efektif.

Guru-guru SD Negeri 1 Teluk Betung Kecamatan Karau Kuala Kabupaten Barito Selatan memang memiliki perbedaan antara satu dan lainnya dalam menyampaikan materi pembelajaran, namun pada umumnya sebelum melaksanakan pembelajaran, guru-guru secara terpadu lebih awal merencanakan materi-materi dan merumuskan kompetensi pembelajaran yang akan disampaikan,

kemudian dirumuskan hasil belajar yang ingin dicapai, dan beberapa indikatornya, serta strategi pembelajaran yang diterapkan.

SD Negeri 1 Teluk Betung Kecamatan Karau Kuala Kabupaten Barito Selatan, telah menerapkan manajemen modern dan professional dengan struktur organisasi yang lengkap dan pembagian kerja yang jelas serta profesional di samping itu pembinaan kerjasama dan perilaku terus menjadi prioritas utama. Hal ini dilakukan dalam rangka memperjelas ruang lingkup kerja, tugas, hak, tanggung jawab, dan wewenang masing-masing pribadi dalam tubuh organisasi SD Negeri 1 Teluk Betung Kecamatan Karau Kuala Kabupaten Barito Selatan, dengan demikian segala bentuk kesalahan seperti tumpang tindih kewenangan dan yang semacamnya dapat dihindarkan. Pembagian tugas secara jelas ini menjadi sangat penting dalam rangka pemberdayaan seluruh SDM yang ada sebagai potensi yang diharapkan secara bersama-sama dapat menjalankan tugas dan tanggung jawab organisasi dalam 
mencapai tujuan yang telah ditetapkan bersama.

Menurut, Indriani bahwa uraian tugas tersebut hanyalah merupakan penggarisan atau batasan yang harus dipertanggung jawabkan masing-masing pengelola secara rutin, karena dalam melaksanakan tugas-tugas tersebut tetap diperlukan adanya kerjasama dari semua warga Sekolah, sehingga terbangun kekompakan atau kebersamaan setiap pelaksanaan program, dan tidak ada sekat dan diskrimininasi antara satu dengan yang lainnya. 22

Berdasarkan keterangan di atas dipahami bahwa pembelajaran di SD Negeri 1 Teluk Betung Kecamatan Karau Kuala Kabupaten Barito Selatan domainnya pada implementasi pendidikan berbasis sekolah yang menekankan pada pelaksanaan Pendidikan yang dalam kenyataannya tidak bersifat statis tetapi bersifat dinamis.

Pelaksanaan pembelajaran di SD Negeri 1 Teluk Betung Kecamatan Karau Kuala Kabupaten Barito Selatan senantiasa berkembang dalam arti kurikulum di SD Negeri 1 Teluk Betung Kecamatan Karau Kuala Kabupaten Barito Selatan selalu mengalami pembaharuan. Ini terjadi dari tahun ketahun sesuai dinamika yang dialami. Data empirik yang mendukung, dapat dilihat dari segi perubahan global yang maju sesuai dengan tuntutan kemajuan ilmu pengetahuan, teknologi dan kebutuhan masyarakat. Pembaharuan tersebut dimaksudkan untuk meningkatkan mutu pembelajaran sehingga pengalaman belajar berguna bagi para lulusan. Berkenaan dengan inilah, maka untuk mencapai tujuan pendidikan yang tertuang dalam kurikulum, harus memenuhi berbagai prinsip yang melandasi kurikulum.

\section{Tujuan dan Sasaran}

Untuk mengetahui lebih lanjut tentang strategi peningkatan pembelajaran melalui pelaksanaan kurikulum pendidikan di SD Negeri 1 Teluk Betung Kecamatan Karau Kuala Kabupaten Barito Selatan, yang didasarkan pada konsep manajemen terlebih dahulu harus dilihat dari segi implementasi kurikulum yang sudah mulai diterapkan dengan pendekatan Menejemen Berbasis Sekolah (MBS).

Berdasarkan hasil penelitian bahwa penerapan manajemen secara umum di SD Negeri 1 Teluk Betung Kecamatan Karau Kuala Kabupaten Barito Selatan dapat dikatakan sudah terimplementasi secara eksplisit, jika dicermati terhadap beberapa keberhasilan yang telah diraih oleh SD Negeri 1 Teluk Betung Kecamatan Karau Kuala Kabupaten Barito Selatan selama tiga tahun terakhir, baik keberhasilan di bidang akademik maupun di bidang non akademik.

Seluruh aktifitas pendidikan harus terfokus kepada upaya memenuhi harapan dan kepuasan peserta didik. Lembaga pendidikan yang memiliki komitmen besar terhadap kepuasan dan kebutuhan peserta didik merupakan hal penting dan utama untuk meraih mutu pendidikan yang mempunyai daya saing yang tinggi.

Hal ini sejalan dengan program pendidikan yang dikembangkan oleh SD Negeri 1 Teluk Betung Kecamatan Karau Kuala Kabupaten Barito Selatan bahwa pada hakekatnya 
Retiana

seluruh aktifitas pendidikan semuanya tertuju atau terfokus kepada peserta didik, baik melalui program kegiatan akademik maupun non akademik. Langkah-langkah peningkatan mutu peserta didik dikelola secara optimal sesuai dengan perencanaan yang telah dirumuskan dalam Rencana Strategis (RENSTRA) dan Rencana Kerja Tahunan (RKT) SD Negeri 1 Teluk Betung Kecamatan Karau Kuala Kabupaten Barito Selatan

Terkait dengan sistem manajemen ke peserta didikan sebagai salah satu kegiatan operasional Sekolah, maka peserta didik sebagai peserta didik utama, harus mendapatkan pelayanan secara berkesinambungan dengan mengatur berbagai kegiatan dalam bidang kepeserta didikan agar kegiatan pembelajaran di Sekolah dapat berjalan lancar, tertib dan teratur, serta mencapai tujuan pendidikan sekolah. Oleh karena itu pengembangannya meliputi kegiatan-kegiatan yang berkaitan dengan peserta didik, mulai masuk sampai ke luar dari Sekolah, dan aspek-aspek lain yang lebih luas yang secara operasional dapat membantu upaya pertumbuhan dan perkembangan pribadi peserta didik secara optimal.

Keberhasilan, kemajuan, dan prestasi belajar peserta didik memerlukan data yang otentik, dapat dipercaya, dan memiliki keabsahan. Oleh karena itu setiap kegiatan didokumentasikan secara khusus oleh bagian Tata Usaha Sekolah dengan menggunakan sistem pendataan berbasis komputer guna memudahkan analisis, pendokumentasian, tentang informasi mengenai data kemajuan peserta didik. Data ini diperlukan untuk dijadikan bahan informasi kepada masyarakat terutama kepada orang tua peserta didik, bahkan menjadi bahan untuk mengetahui dan mengontrol keberhasilan atau prestasi kepala Sekolah bersama dengan guru- gurunya sebagai pengelola pendidikan. Demikian halnya kemajuan belajar peserta didik, secara periodik harus dilaporkan kepada orang tua sebagai masukan untuk berpartisipasi dalam proses pendidikan dan membimbing anaknya belajar di rumah secara kontinyu.

Pemantauan terhadap kemajuan prestasi peserta didik dalam pembelajaran merupakan suatu kegiatan pendahuluan untuk merencanakan strategi pembelajaran, metode apa yang cocok, dan menambah/mengurangi beban kerja. Secara khusus, pemantauan terhadap kemajuan peserta didik yang dilakukan secara konsisten dan kontinu berperan sebagai dasar untuk memberikan balikan kepada peserta didik Dalam kaitan dengan kegiatan ini, perlu diperhatikan aktivitas pekerjaan rumah yang diberikan kepada peserta didik, terutama yang berkaitan dengan seberapa banyak pekerjaan rumah yang selayaknya diberikan kepada peserta didik dan penilaian yang diberikan.

Pendidikan tidak hanya bertujuan untuk mengembangkan pengetahuan peserta didik, tetapi juga sikap kepribadian dan keterampilan-keterampilan lain, yang lahir dari hasil pengalaman proses pembelajaran di Sekolah. Sekolah tidak hanya bertanggung jawab memberikan berbagai ilmu pengetahuan dan keterampilan, tetapi juga memberi bimbingan dan bantuan terhadap peserta didik

yang bermasalah, baik dalam belajar, maupun emosional dan tingkah lakunya, sehingga dapat tumbuh dan berkembang secara optimal sesuai dengan potensi masing-masing. 
Pengembangan peserta didik dalam hal bakat dan minat dapat melalui organisasi peserta didik Sekolah dengan mengisi berbagai kegiatan berupa pengetahuan dan keterampilan khusus.

Fokus utama dalam aktivitas pembelajaran di Sekolah adalah peserta didik, mereka merupakan subjek utama proses pembelajaran. Berhasil atau tidaknya proses pembelajaran sangat tergantung pada kesiapan dan kemampuan peserta didik untuk belajar. Optimalisasi kesiapan dan kemampuan belajar menjadi kunci keberhasilan proses pembelajaran di Sekolah. Sekolah yang efektif harus menyediakan program dan aktivitas pelayanan pendukung peserta didik (Student Support Services). Program dan aktivitas layanan ini diarahkan untuk membantu peserta didik mengaktualisasi potensinya secara optimal.

Kepemimpinan Kepala SD Negeri 1 Teluk Betung Kecamatan Karau Kuala Kabupaten Barito Selatan selalu menawarkan solusi alternatif dalam pengembangan pendidikan ke depan, sistem pendidikan di Sekolah harus diperbaharui dan dikembangkan; kurikulum harus ditingkatkan dengan merumuskan indikator yang relevan dengan kebutuhan peserta didik. Pada saat yang sama, metodologi pembelajaran harus semakin ditingkatkan sesuai dengan karakteristik materi bahan ajar yang diajarkan kepada peserta didik. Metodologi yang bervariasi sangat efektif untuk mendorong peserta didik menganalisis dan mengkritik apa yang mereka dapat dari pengajar.

Dalam menghadapi persaingan eksternal yang semakin ketat, terutama di sektor pendidikan, maka Sekolah harus selalu mengadakan perbaikan secara berkesinambungan, dengan kata lain harus melakukan upaya perubahan dan menjadikan sesuatu lebih baik dari sebelumnya atau menimal mepertahankan mutu dan prestasi yang telah dicapai. Ada beberapa komponen pendidikan yang perlu mendapat perbaikan kualitas secara berkesinambungan, yaitu, 1) perbaikan proses pembelajaran, 2) perbaikan metode dan media pembelajaran, dan 3) pengembangan/ peningkatan kinerja guru dan staf.

Kurikulum dan pembelajaran merupakan dua komponen yang tidak bisa dipisahkan, karena boleh dikatakan keduanya saling terkait. Kurikulum sebagai pedoman acuan pelaksanaan pembelajaran membutuhkan perubahan dan pengembangan sesuai dengan kemajuan dan tuntutan zaman. Kurikulum yang berisikan seperangkat perencanaan yang mengatur pendidikan melalui proses pembelajaran peserta didik, sangat erat kaitannya dengan kebutuhan peserta didik dan masyarakat, agar hasil proses pembelajaran yang dituntut didalam kompetensi kelulusan dapat menjawab tantangan maupun kebutuhan zaman dalam proses kehidupan.

Selanjutnya, dijelaskan bahwa dalam melaksanakan pembelajaran harus disesuaikan dengan Kurikulum 2013, guru-guru harus menguasai materi pokok yang akan diajarkan kepada peserta didik dalam rangka pencapaian Kompetensi Inti dan kompetensi dasar, semua guru pada SD Negeri 1 Teluk Betung Kecamatan Karau Kuala Kabupaten Barito Selatan sudah dibekali pengetahuan tentang pengelolaan kelas, dan semua mata pelajaran berdasarkan struktur kurikulum yang ditetapkan dalam kurikulum 2013. 
Retiana

\section{Rencana kegiatan}

Pembelajaran merupakan sebuah peristiwa belajar yang bertujuan mencapai penguasan kompetensi. Untuk mencapai kompetensi yang telah direncanakan dibutuhkan pengelolaan pembelajaran yang baik. Pembelajaran akan berhasil manakala direncanakan dengan matang, dilaksanakan dengan baik dan dievaluasi sesuai dengan kaedah evaluasi sehingga evaluasi benar-benar mampu mengukur sesuatu yang seharusnya diukur.

Penyusunan perangkat pembelajaran di SD Negeri 1 Teluk Betung Kecamatan Karau Kuala Kabupaten Barito Selatan, wajib dilakukan. Setiap guru di wajibkan menyusun dan memiliki perangkat pembelajaran. Hal ini dilakukan karena dengan adanya perangkat pembelajaran para guru dapat mempersiapkan diri dalam melakukan pembelajaran, dan mengetahui langkah-langkah yang akan dilakukan dalam pembelajaran. Setiap guru memiliki perangkat pembelajaran, sebab di dalamnya berisi tentang kompetensi yang harus dicapai anak, metode dan strategi pembelajaran yang di gunakan evaluasi yang akan dilakukan, dan waktu pelaksanaan kegiatan pembelajaran. Dalam hal ini suatu langkah yang positif yang patut di beri apresiasi karena perangkat pembelajaran merupakan pedoman pelaksanaan pembelajaran. Arah pembelajaran akan terkontrol dangan adanya dan kompetensi dasar yang diinginkan akan tercapai jika guru dalam melaksanakan pembelajaran menggunakan perangkat pembelajaran.

Dalam merencanakan pembelajaran, guru di sekolah tersebut menyusun rencana pembelajaran dengan memperhatikan pengetahuan yang dimiliki dan dibawa oleh peserta didik, menekankan aspek kognitif, psikomotor dan afektif serta kontekstual.

Perangkat pembelajaran yang di susun pada sekolah ini ternyata baik guru PNS maupun non PNS telah memiliki perangkat pembelajaran, meliputi program tahunan, program semester, KKM, silabus, dan RPP, perangkat pembelajaran ini dijilid dan ditanda tangani oleh kepala sekolah.

Dengan demikian perencanaan pembelajaran telah diakukan dengan baik pada sekolah ini baik menyangkut penyusunan dokumen kurikulum, maupun perangkat pembelajaran yang berisi program tahunan, program semester, KKM, silabus dan rencana pelaksnaan pembelajaran (RPP). RPP ini berisi rencana pembelajaran yang akan dilaksanakan, kompetensi dasar yang harus dikuasai oleh sisiwa, alokasi siswa, metode dan model pembelajaran yang digunakan, dan evaluasi belajar yang akan diujikan.

\section{Solusi}

Solusi implementasi supervisi kepala sekolah dalam peningkatan pembelajaran di SD Negeri 1 Teluk Betung Kecamatan Karau Kuala Kabupaten Barito Selatan yaitu kepala sekolah sangat perlu memberi pengawasan dan petunjuk dalam peningkatan pembelajaran di SD Negeri 1 Teluk Betung Kecamatan Karau Kuala Kabupaten Barito Selatan sesuai tugasnya sebagai supervisor ialah mencakup kegiatan atau usaha untuk membangkitkan dan 
merangsang para guru dan pegawai untuk melaksanakan tugasnya.

Sedangkan secara khusus tugas dan tanggung jawab kepala sekolah sebagai supervisor yaitu melaksanakan kegiatan berupa: 1) mendiskusikan tujuan-tujuan pendidikan di SD Negeri 1 Teluk Betung Kecamatan Karau Kuala Kabupaten Barito Selatan dengan guru-guru; 2) mendiskusikan tentang metode-metode dan tehnik-tehnik pembuatan RPP dan penyediaan bahan ajar; 3) membimbing guru dalam penyusunan perangkat pembelajaran; 4) membimbing guru dalam memilih dan menilai buku-buku perpustakaan sekolah, buku-buku pelajaran untuk peserta didik.

Tugas dan tanggung jawab kepala sekolah dalam supervisi di SD Negeri 1 Teluk Betung Kecamatan Karau Kuala Kabupaten Barito Selatan yaitu: 1) melakukan perencanaan kegiatan yang akan dilakukan disekolah bersama guru; 2) melakukan pengorganisasian kegiatan di SD Negeri 1 Teluk Betung Kecamatan Karau Kuala Kabupaten Barito Selatan ; 3) melakukan kegiatan supervisi terhadap aktivitas yang akan dilakukan oleh guru; 4)menilai proses kerja dan hasil kerja yang dicapai oleh guru dalam melakukan proses pembelajaran.

Berdasarkan uraian diatas tugas dan tanggungjawab kepala sekolah dalam pelaksanaan supervisi sekolah di SD Negeri 1 Teluk Betung Kecamatan Karau Kuala Kabupaten Barito Selatan meliputi: 1) membantu para guru secara individual dan kelompok memecahkan masalah pengajaran yang mereka hadapi; 2) mengkoordinasikan semua usaha pengajaran menjadi pengaruh edukatif yang teritegrasi dengan baik; 3) mengadakan program latihan dalam jabatan yang terus menerus bagi guru; 4) membangun suatu usaha ilmiah yang berhubungan dengan penilaian dan perbaikan program di sekolah; 5) memperoleh alat-alat pelajaran yang bermutu dan mencukupi; 6) membangkitka dan memelihara kegairahan guru yang kuat untuk mencapai prestasi kerja yang semakin baik; dan 7) membangun hubungan yang baik dan kerja sama dan produktif antar sekolah dan lembaga sosial masyarakat.

Hal tersebut relevan dengan pandangan peneliti bahwa: tugas atau fungsi tanggung jawab kepala sekolah sebagai supervisor ialah melaksanakan kegiatan berupa:

1) Mendiskusikan tentang tujuan-tujuan dan falsafah pendidikan dengan guru-guru di sekolah;

2) Mendiskusikan tentang metode-metode dan teknik-teknik mengajar dalam rangka pembinaan dan pengembangan proses belajar mengajar kepada guru-guru;

3) Membimbing guru-guru dalam penyusunan dalam satuan pelajaran, program semesteran, dan pengembangan silabus;

4) Membimbing guru-guru dan menginterpretasi hasil tes dan penggunaannya bagi perbaikan proses belajar mengajar.

5) Membimbing guru-guru dalam menganalisis dan menginterpertasi hasil tes dan penggunaannya bagi perbaikan proses belajar mengajar.

Berdasarkan hasil penelitian seperti telah diuraikan diatas, maka penulis mengemukakan solusi yaitu tugas dan tanggung jawab kepala sekolah dalam melaksanakan supervisi di sekolah perlu dilakukan untuk meningkatkan kinerja seluruh komponen 
Retiana

pendidikan dan peningkatan mutu pendidikan, dan kontribusi supervisi kepala sekolah dalam meningkatkan kinerja guru perlu ditingkatkan sehingga tercipta peningkatan mutu pendidikan, kedisiplinan semangat kerja sehingga tercapai tujuan pendidikan yang diharapkan.

\section{Kesimpulan}

Implementasi supervisi kepala sekolah di SD Negeri 1 Teluk Betung Kecamatan Karau Kuala Kabupaten Barito Selatan bahwa kepala sekolah mempunyai tiga tugas dan tanggung jawab. a) mengidentifikasi masalah-masalah pengajaran, b) bertindak sebagai seorang nara sumber, c ) memiliki kecakapan dalam melakukan komunikasi dengan para guru, dan staf sekolah serta berupaya mengimplementasikan supervisi kepala sekolah.

Strategi Peningkatan pembelajaran di SD Negeri 1 Teluk Betung Kecamatan Karau Kuala Kabupaten Barito Selatan berada dalam kategori baik dimana guru melakukan perencanaan pembelajaran satu bulan sebelum pelaksanaan pembelajaran dilaksanakan, meliputi program tahunan, program semester, pemetaan materi, silabus, rencana pelaksanaan pembelajaran (RPP), dan kriteria ketuntasan minimal (KKM), Rencana program pembelajaran berisi standar kompetensi (SK), kompetensi dasar KD), rencana materi yang diajarkan, metode dan model pembelajaran, serta sumber dan alat yang akan digunakan, rencana pelaksanaan evaluasi, dan alokasi waktu yang digunakan. Dari segi pelaksanaan pembelajaran berpedoman pada rencana program yang telah disusun. Kemudian evaluasi dilakukan setelah peserta didik menyelesaikan pembelaaran dalam kurun waktu sesuai rencana kegiatan. Peserta didik yang memperoleh nilai diatas KKM di beri pengayaan dan peserta didik dibawah nilai KKM maka diberi remedial. 
Implementasi Supervisi Kepala Sekolah Dalam Peningkatan Strategi Pembelajaran

\section{Bibliografi}

Arikunto, Suharsimi. Organisasi dan Administrasi Pendidikan Teknologi Kejuruan, Jakarta: Rajawali, 2000.

Banun, Muslim Sri, Supervisi Pendidikan Meningkatkan Kualitas Profesionaisme Guru, Cet II, Bandung: alfabeta, 2010.

Daryanto dan Muhammad Farid. Konsep Dasar Manajemen Pendidikan Di Sekolah Dasar.cet. I; Yogyakarta: penerbit Gava Media, 2013.

Daryanto dan Tutik Rachmawati.Supervisi Pembelajaran Inspeksi Meliputu: Controlling, Correcting, Judging, Directing Demonstrasion. cet. I; Yogyakarta: Penerbit Gaya Media, 2015.

Departemen Pendidikan dan Kebudayaan, Pedoman Supervisi dan pembinaan Profesional Guru Sekolah Dasar. Jakarta : 2009.

Engkoswara, Paradigma Manajemen Pendidikan. Menyongsong Otonomi Daerah. Bandung. Yayasan Amal Keluarga, 2012.

Fattah, Nanang. Landasan Manajemen Pendidikan. Cet. V ; Bandung : Remaja Rosdakarya, 2000.

Hamalik, Oemar. Perencanaan Pengajaran Berdasarkan Pendekatan Sistem. Cet. I; Jakarta: Bumi Aksara, 2007.

Hendiyat Soetopo \& Wasty Soemanto, Kepemimpinan dan Supervisi Pendidikan Cet. II; Jakarta: Bina Aksara, 2008.

Marzuki, Metodologi Riset. Yogyakarta: t. pn, 2008.

Mataheru, Piet A. Sahertian dan Frans. Prinsip dan Teknik Supervisi Pendidikan, Surabaya:Usaha Nasional, 2011.

Mulyasa, E. Kurikulum Berbasis Kompetensi. PT. Remaja Rosdakarya, Bandung: 2003.

N.S. Degeng, Buku Pegangan Teknologi Pendidikan Pusat Antar Universitas untuk Peningkatan dan Pengembangan Aktivitas Instruksional Universitas Terbuka. 
Retiana

Jakarta: Depdikbud RI, Dirjen Dikti, 2003.

Pidarta, Made. Pemikiran Tentang Supervisi Pendidikan. Cet. III; Jakarta : Bumi Aksara, 2012.

Purwanto, Ngalim Administrasi dan Supervisi Pendidikan. Bandung: PT Remaja Rosdakarya, 2007.

Rohmanto, Zainal Aqib, Elham. Membangun Profesionalisme Guru dan Pengawas Sekolah. Bandung: CV.Yrama Widya,2008.

Sahertian, Piet A. Konsep Dasar dan Teknik Supervisi Pendidikan Dalam Rangka Pengembangan Sumber Daya Manusia. Jakarta : Rineka Cipta, 2010.

Satori, Djam'an. Efektfitas Sistem Supervisi Sekolah Dalam Rangka Pembinaan Profesional Guru. Bandung:UPI, 2005.

Sagala, Syaiful. Supervisi Pembelajaran Dalam Profesi Pendidikan (Cet. I; Bandung: Alfabeta, 2010.

Soemanto, Hendiyat Soetopo dan Wasty Kepemimpinan dan Supervisi Pendidikan. Jakarta: Bina Aksara, 2008.

Sudirman, Implementasi Manajamen Mutu Terpadu. Total Quality Management) pada Madrasah Aliyah Negeri Pangkep, Tesis Magister. Makassar: Program Pascasarjana UMI, 2007.

Sugiyono, Metode Penelitian PendidikanPendekatan Kualitatif, Kualitatif, dan R\&D. Bandung: Alfabeta, 2008.

Syah, Darwyn. Perencanaan Sistem Pengajaran Pendidikan Agama Islam. Cet. II; Jakarta: Putra Garafika, 2007.

Soetopo Hendiyat \& Soemanto Wasty, Kepemimpinan dan Supervisi Pendidikan. Cet. II; Jakarta: Bina Aksara, 2008. 